\title{
Isolation and Identification of Fungi Causing Damping-off Disease in Onion (Alium cepa L.) Plants
}

\author{
M.S. Rathore and Avinash D. Patil*
}

Department of Botany, Bhopal Nobles' University, Udaipur-313001, Rajasthan, India

*Corresponding author

\section{A B S T R A C T}

\section{Keywords}

Damping-off, invitro, Isolation, Pure culture and PDA

Article Info

Accepted:

18 July 2019

Available Online:

10 August 2019
Damping-off is a serious disease condition caused by fungi affecting seeds and seedlings in both nursery and field conditions. An around 40 to 50, damping-off affected diseased sample of onion seedlings were collected from the onion crop nursery and the adjoining main fields in and around Udaipur district of Rajasthan. These collected samples were subjected for the fungal isolation, on potato dextrose agar (PDA) medium under the invitro condition. Fungi with the distinct colony were picked up and subjected for pure culturing. The isolated fungi were identified as Fusarium solani, Sclerotium rolfsii.

\section{Introduction}

Damping-off is a serious disease affecting seeds and seedlings under nursery, green house and field conditions. This disease is caused by Fusarium spp., Pythium spp., Rhizoctonia spp., Colletotrichum spp. and Sclerotium spp. Post-emergent damping-off disease affected seedlings are weakened first and later killed. Where as in pre-emergent damping-off, infected seeds fail to emerge under severe infestation. Damping-off disease become more severe with the approach of congenial environment such as wet and cool weather conditions and may results in 6070\% damage (Koenning, 2001).

Damping-off pathogens spreads through irrigation water and soil working equipments. Damping-off pathogens attacks the collar region of seedlings on the surface of soil (McGovern et al., 2001). Water soaked, greasy lesions appear on the hypocotyls and roots after the plant emerge and make the plant to collapse and wilt (Cerkauskas, 2001; Fry, 2004). Onion is affected by number of pest and diseases during its growth stages. Damping-off affects onion (Alium cepa L.) 
crop both in nursery and in field condition and bring down the yield of onion drastically. Damping-off in onion caused by the fungal pathogens viz., Pythium spp., Fusarium spp. (Schlecht), Rhizoctonia spp. (Kühn), Sclerotium spp. Even though the damping-off in onion is a serious disease, the yield loss in onion due to this disease is least reported. When the disease occurs in nursery, the delicate seedlings are easily wiped out within a short period of time. Disease spreads in the direction of irrigation water. Damping-off become a complex disease, when it caused by several fungal pathogens, which becomes difficult to control the disease. In case of mild infection by these pathogens, it reduces the shelf life of the bulbs in onion crop. Soil is a dynamic system, managing the soil borne disease is a very challenging and difficult task (Green and Jansen, 2000).

In this research work, efforts have been made to isolate the fungi from the damping-off affected onion crop and to study the fungi under in-vitro conditions, as a basic step towards understanding their biology and further managing them with the eco- friendly manner.

\section{Materials and Methods}

\section{Collection and isolation of fungi}

Studies were carried out at the Department of Botany, Faculty of Science, B. N University, Udaipur district of Rajasthan. Around 40-50, damping-off diseases affected onion seedling samples were randomly collected from nursery and the adjoining field from Udaipur region. The diseased plants were collected in the polythene bags and were transported to the laboratory for the purpose of isolating damping-off pathogens from the infected root bits. Infected root bits of samples were gently washed under tap water for about a minute to remove any dirt and soil particles. The root pieces $(0.5 \mathrm{~cm})$ were dipped in $0.01 \% \mathrm{HgCl}_{2}$ for about 15 seconds and then passed from three washes of distilled sterile water for 2-3 minutes each to remove the traces of $\mathrm{HgCl}_{2}$. The treated root pieces were dried completely in the aseptic condition and then transferred to Petri plates containing sterilized potatodextrose agar (PDA) medium at the rate of 56 pieces/ Petri plate. All the Petri plates were kept at $25 \pm 2{ }^{\circ} \mathrm{C}$ for 7 days. The colonies which were showing distinct mycelial growth habit were segregated by hyphal tips and transferred on to the fresh potato dextrose agar (PDA) medium (Plate-1). The purified fungus cultures were maintained on PDA slants in test tubes for further studies (Plateland 2). The growth is subcultured/multiplied whenever needed during the entire study. Isolated pure fungal cultures were sent to Agharkar Research Institute, Pune for the purpose of fungal identification.

\section{Results and Discussion}

Fungi were identified by Agharkar Research Institute, Pune as Fusarium solani (Mart.) Sacc. (Current name: Neocosmospora solani (Mart.) L. Lombard and Crous), Sclerotium rolfsii Sacc (Current name: Athalia rolfsii (Curzi) C.C. Tu and Kimbr.), Previous research works also provides evidences where Fusarium solani and Sclerotium rolfsii have been isolated from several host plants affected by damping-off disease (Mueller, 2002; Najat, 2012 and El Mohamedy, 2014). Fusarium solani (Current name: Neocosmospora solani (Mart.) L. Lombard and Crous) is a soilborne fungal plant pathogen found in agricultural soils marking a worldwide presence. Chief host plants of this pathogens are potato, tomato, chilli, onion, brinjol, bean, pea and all the members of cucurbitacea family such as water melon, musk melon, cucumber, bottle guard, ridge guard and squash guard. Fusarium solani induces plants to undergo damping-off, root rot, stem rot, surface rot 
and corn rot. $F$. solani produces scarce to plentiful white to cream colored mycelium on potato dextrose agar (PDA) medium. Colonies of $F$. solani are fast growing, develops variable color and texture, sometimes granular to fluffy, rose-red color, purple, or lavender color (Plate-1). Colony starts out as white, cottony growth that gradually turns dark with maturity (Zaccardelli et al., 2008).

Sclerotium rolfsii Sacc (Current name: Athalia rolfsii (Curzi) C.C. Tu and Kimbr.), is also one of the most destructive fungal pathogens able to cause root rot and dampingoff disease on about 500 plant species across 100 plant families, including several crops of economic importance. Plants viz., tomato, potato, pepper, cantaloupe, celery, carrot, cabbage, bean, eggplant, and peanut are also affected by the pathogen. $S$. rolfsii is an aerobic basidiomycete fungus. Primary growth consists of vegetative mycelia that are white and fluffy The optimal temperature range for mycelium growth and sclerotia production are between $27-30{ }^{\circ} \mathrm{C}$. Sclerotia are the reproductive propagules produced by S. rolfsii and are not truly spores, but are composed of highly compacted, melanized hyphae. Sclerotia are the hard, round structures, produced from the main fungal hyphal strands about seven days after infection and measures from $0.3 \mathrm{~mm}$ to 2.0 $3.0 \mathrm{~mm}$ in diameter. Sclerotia which are initially white, turns yellow, tan, or brown colour as they mature. During sclerotium development, drops of clear exudates are produced at the surface on the PDA media under in-vitro conditions. Theses clear exudates contain proteins, cations, amino acids, carbohydrates, enzymes, and oxalic acid (Plate-3). However, droplets do not appear on the sclerotia surface in soil or in cultures exposed to ambient air (Christias, 1980). Nutrient composition of mature sclerotia consists of amino acids, fatty acids, sugars and lipids (Liu and Wu, 1971).

Plate.1 Fusarium solani and Sclerotium rolfsii on PDA Petri plate

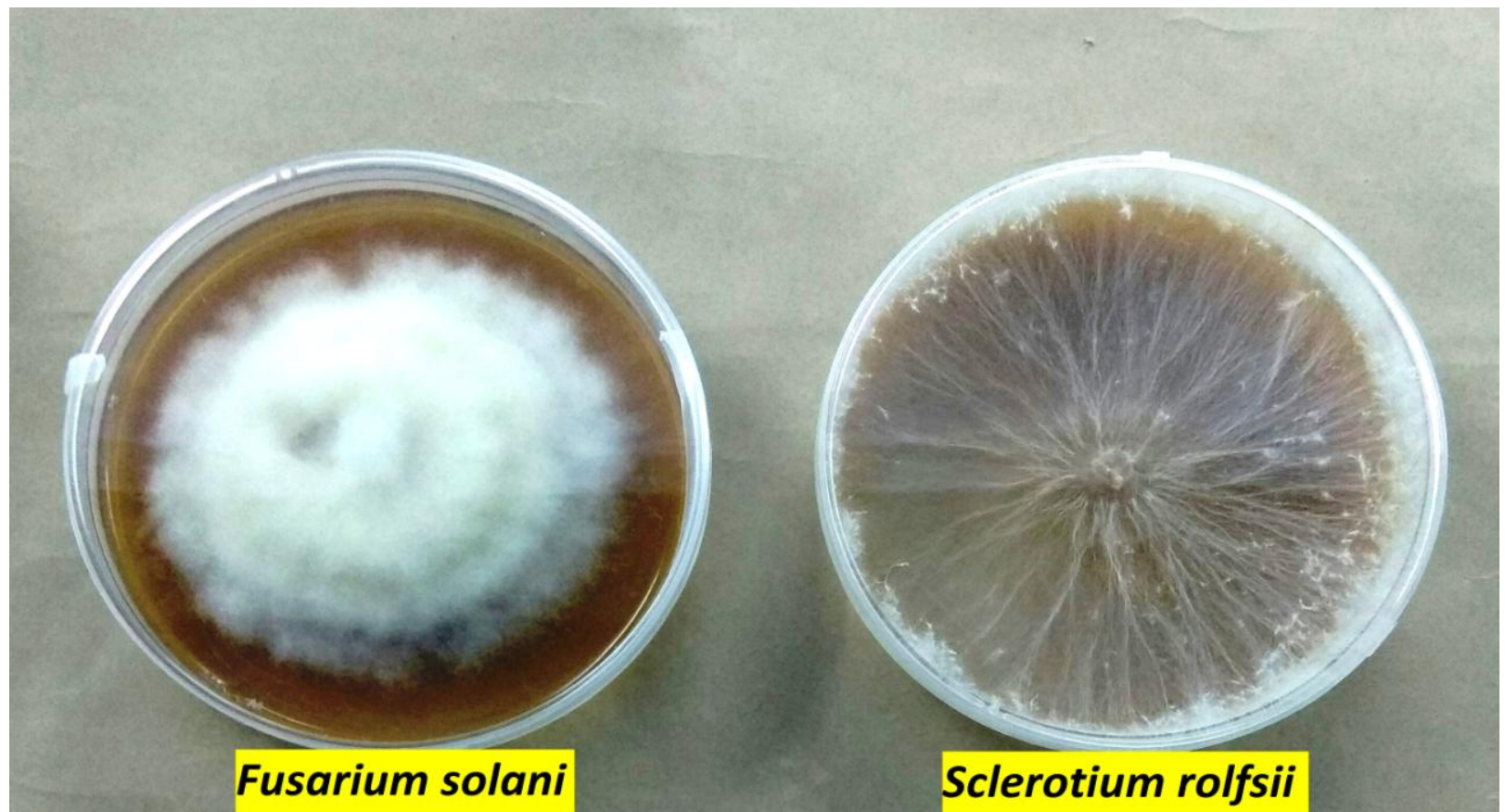


Plate.2 Fusarium solani and Sclerotium rolfsii on PDA slants

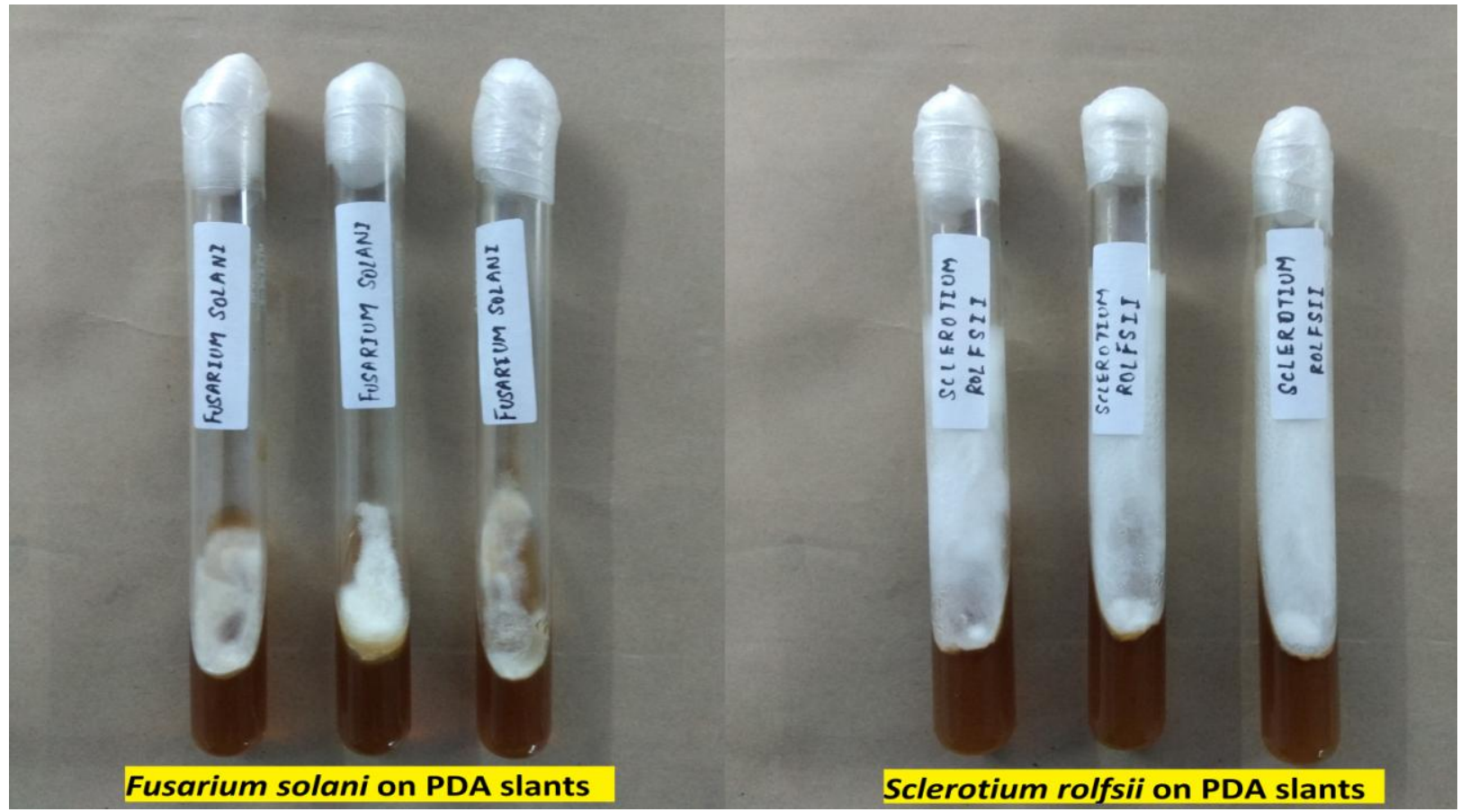

Plate.3 Sclerotia and exudates produced by Sclerotium rolfsii on PDA Petri plate

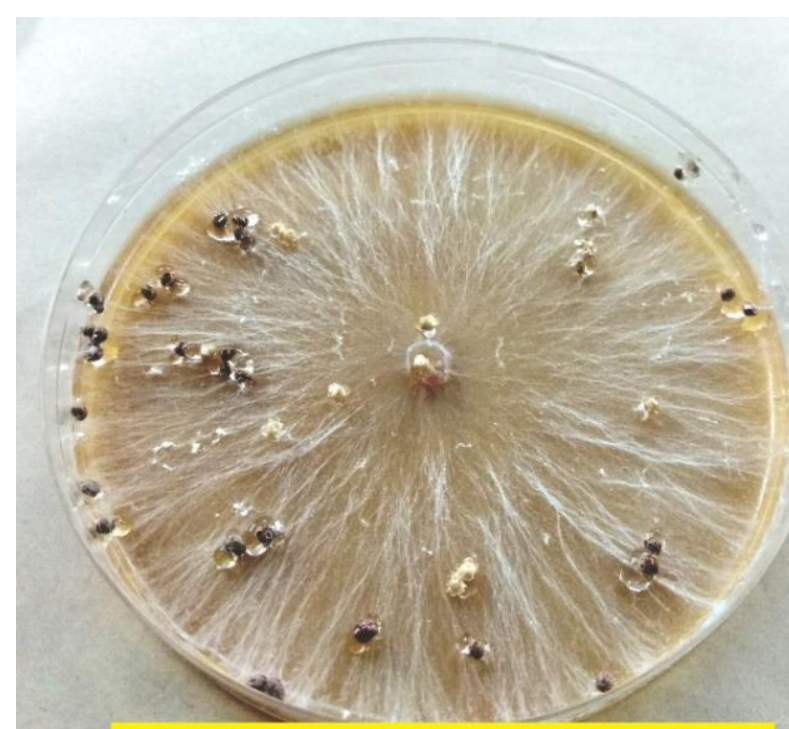

Sclerotia produced on PDA plate

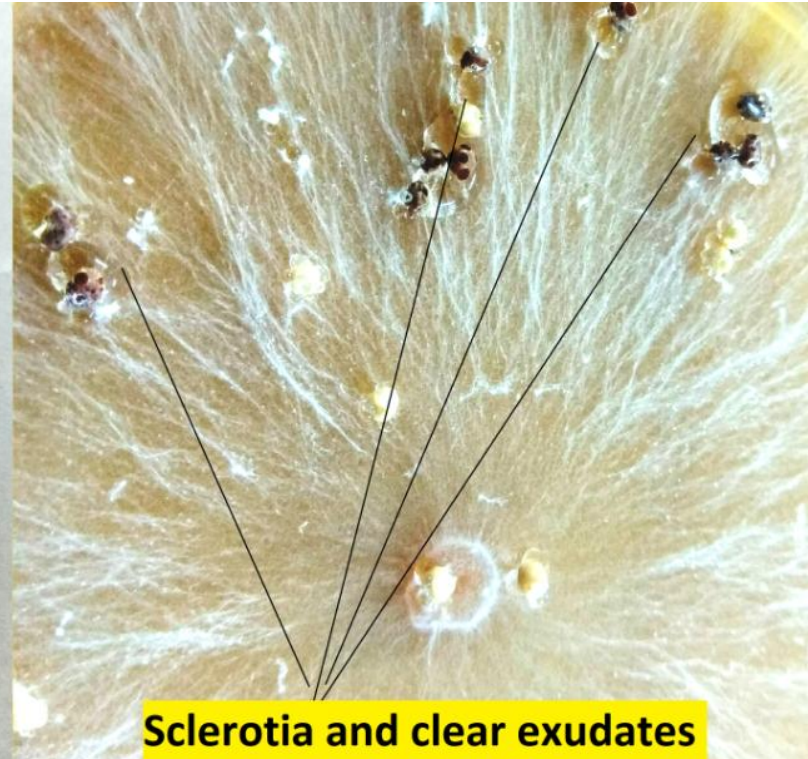

Sclerotia and clear exudates

\section{References}

Cerkauskas, R. 2001. Fusarium Stem and Fruit Rot of Greenhouse Pepper. Ministry of Agriculture and Food. Fact sheet. Government of Ontario, Canada. Pp 1-8.

Christias, C., 1980, Nature of the sclerotial exudate of Sclerotium rolfsii Sacc. Soil Biol. Biochem. 12, 199-201. 
El Mohamedy, R. S. R., Jabnoun Khiareddine, H. and Daami Remadi, M., 2014. Control of root rot diseases of tomato plants caused by Fusarium solani, Rhizoctonia solani and Sclerotium rolfsii using different chemical plant resistance inducers. Tun. J. Plant Prot. 9, 45-55.

Fry, P., 2004. Toxic mold, black mold, mold problems and mold damage information center. mold inspector laboratory international Ltd, United States of America. Pp 1-5.

Green, H. and Jansen, D. F., 2000. Disease progression by active mycelial growth and biocontrol of Pythium var. ultimum studied using a rhizobox system. Phytopathology, 90, 1049-1055.

Koenning, S. 2001. Soybean Sudden Death Syndrome, Soybean Disease Information Note 7. Plant Pathology Extension, North Carolina State University, Raleigh, NC.

Liu, M. F., Wu, L.C., 1971. The effect of amino acids on the growth and morphogenesis of Sclerotium rolfsii Sacc. Plant Prot. Bull., (Taiwan) 13, 87
$-96$.

Mc Govern, R. J., Elmer, W. H., Geiser, D. M. and Harbaugh, B. K., 2001. Biology, epidemiology, and integrated management of diseases caused by Fusarium in potted ornamentals. Department of Plant Pathology, University of Florida, Gainesville. United States of America. Pp 1-5.

Mueller, D. S., Hartman, G. L. and Nelson, R. L., 2002. Evaluation of Glycine max germplasm for resistance to Fusarium solani f. sp. glycines. Plant Disease. 86, 741- 746.

Najat, A., Bokhari and Kahkashan P., 2012, Antagonistic action of Trichoderma harzianum and Trichoderma viride against Fusarium solani causing root rot of tomato. Afr. J. Microbiol. Res. 6(44), 7193-7197.

Zaccardelli, M., Vitale, S., Luongo, L., Merighi, M., Corazza, L. 2008. Morphological and Molecular Characterization of Fusarium solani Isolates. J. Phytopathology: 156, 534541.

\section{How to cite this article:}

Rathore, M.S. and Avinash D. Patil. 2019. Isolation and Identification of Fungi Causing Damping-off Disease in Onion (Alium cepa L.) Plants. Int.J.Curr.Microbiol.App.Sci. 8(08): 2277-2281. doi: https://doi.org/10.20546/ijcmas.2019.808.264 